\title{
Harnessing Soil Microbes to Improve Plant Phosphate Efficiency in Cropping Systems
}

\author{
Arjun Kafle ${ }^{1,+}{ }^{(}$, Kevin R. Cope ${ }^{2,+} \mathbb{C}^{-}$, Rachel Raths ${ }^{2}$, Jaya Krishna Yakha ${ }^{2}$, \\ Senthil Subramanian ${ }^{2,3}$ (D) Heike Bücking ${ }^{2}(\mathbb{D})$ and Kevin Garcia ${ }^{1, *(1)}$ \\ 1 Department of Crop and Soil Sciences, North Carolina State University, Raleigh, NC 27695-7619, USA; \\ akafle@ncsu.edu \\ 2 Biology and Microbiology Department, South Dakota State University, Brookings, SD 57007, USA; \\ Kevin.Cope@sdstate.edu (K.R.C.); rachel.raths@agnition.com (R.R.); Jaya.Yakha@sdstate.edu (J.K.Y.); \\ Senthil.Subramanian@sdstate.edu (S.S.); Heike.Bucking@sdstate.edu (H.B.) \\ 3 Department of Agronomy, Horticulture and Plant Science, South Dakota State University, \\ Brookings, SD 57007, USA \\ * Correspondence: kgarcia2@ncsu.edu; Tel.: +1-919-515-2040 \\ + These Authors contributed equally to the work.
}

Received: 9 February 2019; Accepted: 5 March 2019; Published: 8 March 2019

\begin{abstract}
Phosphorus is an essential macronutrient required for plant growth and development. It is central to many biological processes, including nucleic acid synthesis, respiration, and enzymatic activity. However, the strong adsorption of phosphorus by minerals in the soil decreases its availability to plants, thus reducing the productivity of agricultural and forestry ecosystems. This has resulted in a complete dependence on non-renewable chemical fertilizers that are environmentally damaging. Alternative strategies must be identified and implemented to help crops acquire phosphorus more sustainably. In this review, we highlight recent advances in our understanding and utilization of soil microbes to both solubilize inorganic phosphate from insoluble forms and allocate it directly to crop plants. Specifically, we focus on arbuscular mycorrhizal fungi, ectomycorrhizal fungi, and phosphate-solubilizing bacteria. Each of these play a major role in natural and agroecosystems, and their use as bioinoculants is an increasing trend in agricultural practices.
\end{abstract}

Keywords: arbuscular mycorrhizal symbiosis; ectomycorrhizal symbiosis; phosphate solubilizing bacteria; phosphate efficiency

\section{Introduction}

Phosphorus (P) is a major element that is present in all soils worldwide in both inorganic and organic forms. The inorganic forms are derived from the weathering of primary mineral rock, including various forms of apatite [1]. Upon weathering, inorganic $\mathrm{P}\left(\mathrm{P}_{\mathrm{i}}\right)$ exists in the soil solution as orthophosphates, including $\mathrm{H}_{2} \mathrm{PO}_{4}{ }^{-}$and $\mathrm{HPO}_{4}{ }^{2-}$. Depending on soil conditions, orthophosphates can be adsorbed to mineral complexes, converting them into insoluble forms [2]. In acidic soils, they are bound to both iron and aluminum oxides as well as clay minerals; however, in alkaline soils, they are bound mainly to calcium carbonate [3,4]. In addition, soluble orthophosphates that are not adsorbed are often assimilated into various biological systems; hence, approximately $30-80 \%$ of the $\mathrm{P}$ present in soil is immobilized in various organic forms [5]. The most common form of organic P is inositol phosphate, which makes up approximately $60 \%$ of the total organic $\mathrm{P}$ in the soil [5]. Inositol phosphate is stable and is formed by a series of phosphate esters ranging from monophosphates to hexaphosphates. Phytate, or inositol hexakisphosphate, is the most abundant form of inositol phosphate [6]. Additional forms of organic P include glycerol phosphates, phospholipids, nucleic acids, 
and sugar phosphates; all of these are mainly contained in soil microbial biomass and combined make up less than $2 \%$ of the total soil organic P [7]. All forms of organic P in the soil are not bioavailable, i.e. not readily available for plant uptake, because they have inherently high molecular weights and therefore must be hydrolyzed into soluble inorganic forms, such as orthophosphate [7]. To summarize, although the soil contains large quantities of $\mathrm{P}$, most of it is not available for plants, forcing them to develop different strategies to acquire $P$, including the establishment of symbiotic associations with soil microbes (Figure 1).

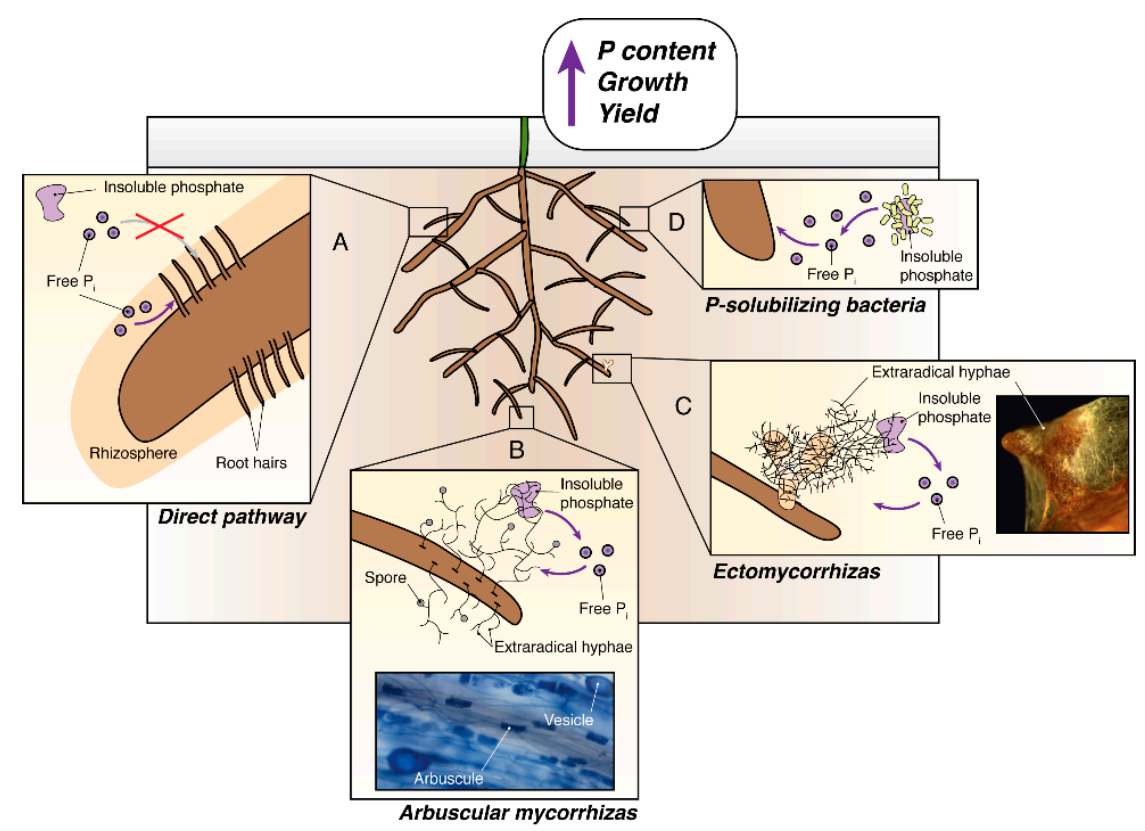

Figure 1. Schematic model showing the acquisition of phosphorus in plants, facilitated by arbuscular mycorrhizal fungi, ectomycorrhizal fungi, and P-solubilizing bacteria. (A) Root hairs on the roots of plants are able to acquire inorganic phosphate $\left(\mathrm{P}_{\mathrm{i}}\right)$ from soil that is within close proximity (e.g., within the rhizosphere). This method of $P_{i}$ acquisition is known as the direct uptake pathway. Insoluble forms of phosphate and free $P_{i}$ that are outside of the rhizosphere cannot be reached by the plant (red cross). (B) Spores of arbuscular mycorrhizal fungi germinate, and emerging hyphae make contact with and penetrate roots in order to form arbuscules and sometimes vesicles in plant cortical cells. Extraradical hyphae exploring the soil can extract $P_{i}$ from insoluble forms of phosphate (e.g., minerals and organic matter) and acquire it. $\mathrm{P}_{\mathrm{i}}$ is then transported through the hyphae colonizing the roots and delivered to plant cells. (C) Specific plant-fungal structures called ectomycorrhizas can be formed on woody plant roots. As with arbuscular mycorrhizas, extraradical hyphae exploring the soil extract $P_{i}$ from insoluble forms and acquire it. These hyphae can sometimes form rhizomorphs that are highly differentiated structures (not represented here). $\mathrm{P}_{\mathrm{i}}$ is transported towards the roots and then delivered to plant cells. (D) Insoluble forms of phosphate are actively degraded by P-solubilizing bacteria. The resulting free $\mathrm{P}_{\mathrm{i}}$ can either be taken up by the roots or other organisms, including mycorrhizal fungi. The improvement of $\mathrm{P}$ acquisition through direct or indirect microbial pathways leads to the increase of $\mathrm{P}$ content in aboveground tissues (e.g., seeds and fruits), thus increasing plant growth and yield.

In plants, $\mathrm{P}$ is a fundamental component of nucleic acids, phospholipids, and energy-shuttling nucleotide triphosphates. As such, $\mathrm{P}$ plays a crucial role in many molecular processes, including nucleic acid synthesis, membrane synthesis and stability, respiration, signal transduction pathways, enzymatic activity, and redox reactions [8-10]. P is also vital for supporting photosynthesis, embryo and seed formation, and biological nitrogen fixation $[9,11]$. Due to the pivotal role of $P$ in plants, its optimal concentration often exceeds $60 \mu \mathrm{mol} \mathrm{g}^{-1}$ of dry mass [12]. However, as described above, the concentration of $\mathrm{P}$ in the soil that is bioavailable to plant roots is quite low, ranging from 1 to $10 \mu \mathrm{M}$ in the form of $P_{i}$ [13]. Thus, when the soil $P$ supply falls short of the plant $\mathrm{P}$ demand, it results in 
multiple adverse effects on plant growth and development, including defoliation, intolerance to biotic and abiotic stressors, and significant yield reduction [14,15].

To combat yield reduction and meet the demand for food of the growing human population, chemical fertilizers, including monoammonium phosphonate, diammonium phosphate, superphosphate, and different formulations of NPK, have been used extensively worldwide since the 1960s to provide additional P [16]. Although this practice has proven effective in temporarily treating the symptoms of $\mathrm{P}$ nutrient deficiency in crops, frequent applications of excess $\mathrm{P}$ fertilizers have detrimental environmental impacts, including the eutrophication of aquatic ecosystems due to the leaching and runoff of residual $P$ from agricultural fields $[8,17,18]$. In addition, $P$ is a non-renewable resource, and the known rock phosphate reserves that currently feed the agronomic $P$ fertilizer demand are unsustainable and estimated to be depleted within 50-100 years [19,20]. Furthermore, rock phosphate also contains heavy metal residues such as arsenic, chromium, lead, mercury, nickel, vanadium, and cadmium, thus contributing to the accumulation of heavy metals in arable land [21]. Finally, between 75 and $90 \%$ of the applied $\mathrm{P}$ is precipitated by iron, aluminum, or calcium complexes present in the soil, making it unavailable to the plant in the first year of application $[8,9,17]$. Poor soil fertility and high $\mathrm{P}$ applications also directly inhibit microorganisms that can naturally improve $\mathrm{P}$ availability in soils $[17,22]$.

Plants adapted to P-deficient soils improve their P acquisition and use efficiency by (1) changing root architectural traits, (2) increasing the rate of $P$ mineralization of rock minerals, (3) remobilizing organic sources of $\mathrm{P}$ via hydrolysis, (4) replacing phospholipids in membranes with sulfo- and galactolipids, or (5) employing metabolic pathways that can conserve P [3,23-25]. The most important adaptation to $\mathrm{P}$ limiting soil conditions, however, is the development of interactions with soil microbes, particularly mycorrhizal fungi [26]. In this review, we describe how plant-associated soil microbes mobilize and deliver $P$ to their host plants. In particular, we summarize key information about how arbuscular mycorrhizal (AM) and ectomycorrhizal (ECM) fungi, as well as phosphate solubilizing bacteria contribute to plant $P$ nutrition. We also describe how these microbes could serve as a sustainable alternative to synthetic $\mathrm{P}$ fertilizers used in agricultural and forestry production.

\section{The Use of Arbuscular Mycorrhizal Symbiosis in Agriculture to Improve Phosphate Uptake}

Plants are able to acquire $P_{i}$ from the soil solution either directly via their own root system, particularly through root hairs (Figure 1A), or indirectly via their symbiotic association with mycorrhizal fungi (Figure 1B,C). Due to the slow rate of $P_{i}$ diffusion in soils, the direct uptake pathway only allows plants to access $P_{i}$ from the rhizosphere $[27,28]$. Root hairs play a crucial role in expanding the root surface area involved in nutrient uptake, especially under low $\mathrm{P}$ conditions [29]. High-affinity transport proteins localized to the outer surface of root epidermal cells absorb $P_{i}$ from the soil solution against the concentration gradient. The activity of these transporters is dependent on the active acidification of the soil solution by the plant, which allows the simultaneous co-transport of $P_{i}$ with hydrogen ions into the plant cell [30].

In natural ecosystems, most land plants also acquire $\mathrm{P}$ through the indirect or mycorrhizal uptake pathway via the extension of their root system through associations with various classes of mycorrhizal fungi. One class includes AM fungi, which are ubiquitous in soils around the globe. They belong to the phylum Mucoromycota, sub-phylum Glomeromycotina, and form a symbiotic association with more than $70 \%$ of land plant species, including many agronomically important crops [31-34]. Among these major crop cereals, legumes, grasses, and trees can be found colonized by AM fungi in the field [33]. Many key plant genes required to form AM associations, and absent from non-mycorrhizal plants, have been identified in model angiosperms in the past few decades [35]. Although AM fungi are ubiquitous, obligate and facultative mycorrhizal host plants vary in their degree of specificity when recruiting AM fungal partners [36]. AM fungi explore the soil for water and mineral nutrients through the development of an extensive extraradical mycelium. The collective soil volume surrounding all extraradical hyphae is referred to as the "mycorrhizosphere" [37,38]. 
Compared to the rhizosphere, the volume of the mycorrhizosphere is orders of magnitude larger, given that the extraradical hyphal networks of AM fungi can extend up to $25 \mathrm{~cm}$ from the plant root into the soil [28]. Inside the root, AM fungi form a network of intercellular hyphae and intracellular nutrient exchange structures in the root cortex, called arbuscules $[39,40]$ and, in some cases, storage structures called vesicles. Plants transfer photosynthetic carbon in the form of sugars $[41,42]$ and lipids $[43,44]$ across the periarbuscular and mycorrhizal interface to the fungal partner $[42,45,46]$. In return, AM fungi provide the plants with water and various nutrients, such as $\mathrm{P}$, nitrogen, sulfur, and trace elements [47]. It is well documented that AM fungi contribute significantly to the $P_{i}$ nutrition of their host plant, particularly under $P_{i}$ limitation [48]. Soil exploring hyphae excrete enzymes that mineralize or mobilize plant unavailable organic and inorganic forms of phosphate (Figure 1B). As soon as $P_{i}$ is taken up into the fungal cytoplasm, it can replenish the metabolically active $P$ pool within the hyphae, or it is further polymerized into polyphosphates that are stored in vacuoles, transported towards the intraradical hyphae, and delivered to the plant host through specific fungal and plant transport proteins at the arbuscular interface $[47,49]$. Most of the $P_{i}$ transporters involved in the direct pathway are downregulated when roots are colonized by AM fungi, and instead mycorrhiza inducible $\mathrm{Pi}$ transporters are expressed in the periarbuscular membrane, indicating a shift from the direct $\mathrm{P}$ uptake pathway towards the mycorrhizal one [50,51].

Among all crops, only legumes have the ability to interact with both AM fungi and the symbiotic nitrogen-fixing bacteria rhizobia. This dual association results in the formation of a unique and highly beneficial tripartite interaction [52-54]. Rhizobia are housed by plants in specialized root nodules that provide an environment conducive for bacteria to convert atmospheric nitrogen $\left(\mathrm{N}_{2}\right)$ into a plant usable form (i.e., ammonium), which is then provided to the plant [55]. In return, host plants allocate photosynthetic carbon to rhizobia residing in the nodules $[53,56]$. Biological nitrogen fixation can satisfy more than $70 \%$ of a host plants' nitrogen demand [57] and contributes to one third of our global agricultural nitrogen needs [58]. Converting one molecule of $\mathrm{N}_{2}$ into plant assimilable ammonium is an energy-expensive reaction requiring 16 molecules of ATP [59]. Therefore, roots with functional nodules need substantially more $P_{i}$ than non-nodulated roots $[53,60]$. Legumes growing in $P_{i}$-limited environments are only poorly nodulated or have reduced nodule growth [60-62]. In sub-Saharan Africa field experiments, $P_{i}$ supplements increased soybean seed yields after an inoculation with rhizobia, highlighting the need for proper $P_{i}$ nutrition in legume cultivation $[63,64]$. Due to their positive impact on P nutrition, AM fungi facilitate biological nitrogen fixation in P-deficient soils [52,53,65-67]. Thus, legumes forming tripartite interactions have accelerated growth, increased photosynthetic and biological $\mathrm{N}_{2}$ fixation rates, and higher nutrient contents than plants colonized by only one root symbiont $[53,54,66,68-70]$.

The majority of agricultural crops develop symbiotic associations with AM fungi; as such, it is crucial for breeding programs to retain this trait within the germplasm of crop species. Retaining the ability of crop species to associate with AM fungi is particularly important, because recent studies revealed that the application of AM fungi to field conditions can improve the growth response and seed yield of some crops, including alfalfa and soybean [31,71-75]. For example, soybean plants that were inoculated with AM fungi, showed similar P contents and seed yields, and had a higher fertilization efficiency than fertilized control plants [73]. The identification of highly compatible AM fungal strains, in combination with management choices, will make the fungal communities durable, thus conferring continuous benefits to host plants; in contrast, when chemical fertilizers are applied to a field, they provide short-term benefits necessitating annual application [76]. Although AM fungi can be seen as an exciting alternative to minimize crop dependency on P fertilizers, their actual impact is currently strongly debated by several groups since contrasting effects of AM colonization on plant $P$ nutrition have been reported [77-79]. Indeed, many uncontrolled factors, including native AM fungal communities, can lead to a high variability in plant growth, nutritional or yield responses $[75,76]$. Nutritional and yield benefits of AM fungi also depend on the crop species or its variety, or the AM species or its fungal isolate $[31,72,80]$. For instance, due to its large root system, wheat typically has 
a lower responsiveness to AM fungi than other crop species [74,81,82]. Altogether, this reflects the importance of intensifying our research efforts to identify crop and fungal combinations that lead to maximum benefits in agricultural systems.

\section{The Use of Ectomycorrhizal Fungi to Improve Phosphate Uptake for Lignocellulosic Biofuel Crops}

From an agronomic standpoint, woody plants are not traditionally grown as crops; however, extensive research has shown that some fast growing species of woody plants (e.g., Populus) can be grown as feedstock for the production of lignocellulosic biofuels [83,84]. For this reason, here we consider the production of lignocellulosic biofuels from an agronomic perspective. Breeding programs have already developed cultivars within the genus Populus that are optimized for biomass yield [85]. In addition, genetically modified Populus lines have been developed with decreased cell wall recalcitrance, thus allowing for greater biomass conversion to bioethanol [86]. Although breeding and molecular approaches have increased biomass yield and improved its conversion to biofuel, respectively, the agroecological context in which perennial biofuel crops will be grown has not been fully evaluated. The term "marginal lands" is used to describe low quality land that is not suitable for the production of food or feed from an economic standpoint, but that could serve as land where adapted biofuel crops can be produced [87]. Although the unsuitability can be due to many edaphic factors, one crucial factor is nutrient availability [88]. To produce sufficient biomass for biofuel production, adequate access to nutrients is essential, particularly since the short rotation coppices used for woody plant biofuel production can rapidly deplete mineral nutrient reserves in the soil $[89,90]$. In temperate and boreal forest ecosystems, trees are often dependent on ECM fungi for obtaining mineral nutrients from the soil via the mycorrhizal uptake pathway (Figure 1C; [91]). In this section, we describe how ECM fungi specifically contribute to $P$ nutrition in forests and can therefore be used to promote the sustainable agronomic production of woody plant biomass for lignocellulosic biofuel production.

In contrast to AM fungi, ECM fungi belong to the fungal phyla Basidiomycota, Ascomycota, and Mucoromycota (sub-phylum Mucoromycotina) [92,93]. ECM fungi only colonize 2\% of plant species, the majority of which are woody plants [34]. However, ECM woody plants are the primary flora of forest ecosystems that cover approximately $30 \%$ of the global terrestrial surface [94]. In temperate and boreal forest ecosystems, up to $95 \%$ of tree short roots are colonized by ECM fungi [95]. These mycobionts can substantially improve the ability of trees to acquire water and nutrients [91] and actively participate in nutrient cycling and carbon sequestration [96,97]. In addition, ECM fungi contribute significantly to the abiotic and biotic stress resistance of their host. Due to the mycorrhizosphere, trees colonized by ECM fungi can extend their exploration in the soil up to multiple meters, depending on the species [28]. In many cases, a large percentage of the nutrient absorbing and actively growing part of the root system is colonized with ECM fungi and enclosed by a fungal sheath that can represent an apoplastic barrier, thus limiting the tree's ability to acquire nutrients via the direct plant uptake pathway (Figure 1C). The hyphae developed by ECM fungi inside tree roots form a network called the Hartig net, where nutrients are exchanged between both partners. As with AM fungi, ECM fungi acquire $P_{i}$ from the soil through specialized transporters [98-100], store it in the vacuoles in the form of polyphosphates [101], transport it towards the Hartig net, and release it into the mycorrhizal interface through transport proteins [102]. ECM plants also express specific transporters to absorb $P_{i}$ directly from the mycorrhizal interface $[49,103]$. The filamentous nature of the mycelia formed by ECM fungi, which sometimes aggregate into highly differentiated structures called rhizomorphs, makes them more efficient than the roots of trees at foraging for mineral nutrients, such as P [104-106]. Multiple studies with multiple tree and fungal species grown at varying $P$ concentrations have demonstrated that plants colonized with ECM fungi acquire significantly more $P_{i}$ than non-mycorrhizal plants [105,107-112]. Furthermore, while foraging in nutrient-rich patches within the soil substrate, tree species that associate with ECM fungi allocate more carbon towards the formation of extraradical hyphae than towards the production of roots [106]. 
ECM fungi are capable of mobilizing $\mathrm{P}$ from both inorganic and organic sources within the soil (Figure 1C). Previous studies under controlled laboratory and field conditions have shown that ECM fungi dissolve inorganic sources of $P$ (e.g., the calcium phosphate-enriched clay apatite) via the excretion of organic acids (e.g., oxalic acid) that they produce using plant-derived carbon $[113,114]$. These studies indicate that the weathering of apatite by the fungus is driven by the allocation of photosynthates from the host plant to the fungus that facilitates the mobilization and uptake of $\mathrm{P}$ that can be delivered to the host plant.

In addition to inorganic sources of $\mathrm{P}, \mathrm{ECM}$ fungi can also extract phosphate from various organic sources and can enzymatically digest inositol hexaphosphate through the production of phosphatases [115,116] (Figure 1C). Phosphatase activity increases as the concentration of $P_{i}$ decreases in the soil substrate [116]. In other studies, even more complex sources of organic P (e.g., leaf litter [117], pollen [118], necromass from dead nematodes [119], and even seeds [120]) were exploited by ECM fungi to liberate $P_{\mathrm{i}}$ and subsequently deliver it to the host plant. Interestingly, ECM fungi can also obtain $\mathrm{P}$ directly through cooperative associations with both living saprotrophic fungi-which decompose dead organic matter [121]—and mycorrhiza helper bacteria—which efficiently solubilize P and increase the colonization of the plant [122].

Due to the ability of ECM fungi to improve P availability for their host plant, ECM fungal inoculants have been used in the horticultural production of woody plants and for reforestation efforts [123,124]. The application of ECM fungal inoculants could be a sustainable approach to improve $\mathrm{P}$ availability when growing woody plants for lignocellulosic biofuel production, particularly on marginal lands with limited P. Future studies should focus on identifying ECM fungal species that provide multiple benefits to crop species used for lignocellulosic biofuel production on marginal lands with limited mineral nutrients such as P.

\section{Phosphate Solubilizing Bacteria and Their Potential to Increase the Phosphate Acquisition of Crops}

Besides mycorrhizal fungi, certain soil bacteria can also play a key role in the soil $\mathrm{P}$ cycle (Figure 1D). According to estimates, up to $50 \%$ of the bacteria in the soil are considered phosphate solubilizing bacteria [125]. The diversity of bacteria having phosphate solubilizing capabilities is quite high and includes one or more bacterial species from the following genera: Bacillus [126-130], Pseudomonas [74,131,132], Arthrobacter [126,133] Enterobacter [129,134-136], Kluyvera [129], Chryseomonas [129], Vibrio, Xanthobacter, Micrococcus, Klebsiella, and more [126,129,137]. These bacterial species act on different sources of $\mathrm{P}$ and have diverse mechanisms for solubilizing $P$ in soils.

The primary method that soil bacteria use to liberate $P_{i}$ from complex sources is by producing organic acids [138-140]. There are several ways by which organic acids can convert insoluble forms of $\mathrm{P}$ into bioavailable forms. These include creating acidic microsites that lower the $\mathrm{pH}$ thus releasing $\mathrm{P}$ from calcium ions, chelating metal ions that typically immobilize $\mathrm{P}$, and occupying exchange sites on soil and mineral ions. Each of these methods increases the levels of $P_{i}$ in the soil solution [141,142]. Soil bacteria can also solubilize inorganic sources of $\mathrm{P}$ by releasing inorganic acids, protons, hydroxyl ions, siderophores, and $\mathrm{CO}_{2}$ [1,143-145].

Soil bacteria primarily mineralize organic $P$ with extracellular enzymes. The main groups of enzymes include non-specific phosphohydrolases (also called phosphatases), phytases, phosphonatases, or C-P lyases. Phosphatases are divided into two groups, acidic or alkaline, and soil bacteria release the optimal phosphatase to solubilize organic $\mathrm{P}$, depending on soil $\mathrm{pH}$. Non-specific phosphatases are the most abundant type and can mineralize the majority of organic $P$ in the soil [146]. Phytase functions in releasing $\mathrm{P}$ from phytic acid (inositol), and phosphonatases and C-P lyases facilitate the release of $\mathrm{P}$ bound in organophosphonates $[147,148]$. Higher levels of nitrogen or carbon lead to increases in the phosphatase activity, most likely due to an increase in microbial activity $[149,150]$; meanwhile, higher $P$ availability leads to a decrease in phosphatase and phytase activity [151,152]. 
There is a growing interest in using $\mathrm{P}$ solubilizing bacteria as biofertilizers to increase the bioavailability of $\mathrm{P}$ in soils used for crop production and to enhance the efficiency of $\mathrm{P}$ fertilizer applications (Figure 1D). Increases in plant performance and/or yield after an inoculation with P-solubilizing bacteria have been shown for many agronomically important crop species, including corn [153], soybean [154], wheat [154,155], rapeseed [156], mung bean [157], and tomatoes [158]. While the periodic application of $\mathrm{P}$ fertilizer has adverse effects on the structure and function of phosphate-solubilizing bacterial communities, the opposite is true when little or no superphosphate is applied [159].

In 2016, market researchers estimated that the global biofertilizer market was worth 787.8 million USD. Phosphate solubilizing bacteria accounted for approximately $15 \%$ of the global biofertilizer revenue, which was the second largest and fastest growing sector [160]. These figures indicate that phosphate solubilizing bacteria have proven to be another viable option as biofertilizers and are increasingly being used commercially to increase the abundance of plant available $\mathrm{P}$ in the rhizosphere.

\section{Conclusions}

In this review, we described three major groups of microbes that participate in the cycling of $\mathrm{P}$ within the soil and that have the potential to enhance the plant $P$ acquisition efficiency in agricultural and forestry ecosystems. However, the variability in responses after inoculation with different fungi or bacteria justifies the need to pursue additional research focused on identifying soil microbes that improve plant phosphate efficiency in cropping systems. More importantly, AM fungi, ECM fungi, and phosphate solubilizing bacteria do not act independently, but affect each others' activities. For example, Populus trees associate simultaneously with AM and ECM fungi, and both fungal partners could benefit from $\mathrm{P}$ that is made available by phosphate solubilizing bacteria. In addition, the presence of these symbioses can also have an effect on the activity of other root symbioses, for example symbiotic nitrogen fixing rhizobia in the tripartite interactions of legumes (reviewed in [161]). Interestingly, additive effects on plant performance due to multiple symbioses is currently under debate [162], showing the importance of pursuing efforts towards the investigation of these complex plant-microbe relationships. These types of studies increase our understanding of the microbial systems that exist in nature and will likely facilitate the development of microbial inocula that are more efficient and optimized for the nutritional needs of plants. In parallel, the knowledge gathered from studying multi-partite mutualistic associations must be considered in breeding programs in order to create crop cultivars that can interact more efficiently with soil microbes and thereby maximize the sustainable use of mineral resources in agricultural and forest ecosystems. Finally, with the current frantic race for the production of bioinoculants produced by an increasing number of start-up companies, there is a need for more stringent quality control checks that should be instituted along with comprehensive field trials to ensure the efficiency, reliability, and sustainability of these commercial products.

Author Contributions: Conceptualization, A.K., K.R.C., H.B. and K.G.; writing-original draft preparation, all authors; writing_-review and editing, all authors; supervision, K.G., H.B., S.S.; funding acquisition, K.G., H.B., and S.S.

Funding: This research was funded by North Carolina Agriculture Research Service (NCARS), the North Carolina Soybean Producers Association (2019-1656), USDA (2017-67014-26530), NSF-PGRP (IOS-1350189), USDA-NIFA-AFRI (2016-67014-24589), the National Science Foundation/EPSCoR Cooperative Agreement \#IIA-1355423, and the SD Agricultural Experiment Station (SD00H543-15).

Acknowledgments: K.G. and A.K. acknowledge support of the North Carolina Agriculture Research Service (NCARS) and the North Carolina Soybean Producers Association (2019-1656). H.B., K.R.C, R.R., and J.K.Y. acknowledge funding from the USDA (2017-67014-26530), the SD Soybean Research and Promotion Council, and the Agricultural Experiment Station at South Dakota State University. S.S. acknowledge funding from NSF-PGRP (IOS-1350189), USDA-NIFA-AFRI (2016-67014-24589), the National Science Foundation/EPSCoR Cooperative Agreement \#IIA-1355423, and the SD Agricultural Experiment Station (SD00H543-15).

Conflicts of Interest: The authors declare no conflict of interest. 


\section{References}

1. Rodríguez, H.; Fraga, R. Phosphate solubilizing bacteria and their role in plant growth promotion. Biotechnol. Adv. 1999, 17, 319-339. [CrossRef]

2. Kruse, J.; Abraham, M.; Amelung, W.; Baum, C.; Bol, R.; Kühn, O.; Lewandowski, H.; Niederberger, J.; Oelmann, Y.; Rüger, C.; et al. Innovative methods in soil phosphorus research: A review. J. Plant Nutr. Soil Sci. 2015, 178, 43-88. [CrossRef] [PubMed]

3. Hinsinger, P. Bioavailability of soil inorganic $\mathrm{P}$ in the rhizosphere as affected by root-induced chemical changes: A review. Plant Soil 2001, 237, 173-195. [CrossRef]

4. Matar, A.; Torrent, J.; Ryan, J. Soil and fertilizer phosphorus and crop responses in the dryland Mediterranean zone. In Advances in Soil Science; Stewart, B.A., Ed.; Springer: New York, NY, USA, 1992; pp. 81-146. ISBN 978-1-4612-2844-8.

5. Dalai, R.C. Soil organic phosphorus. Adv. Agron. 1977, 29, 83-117.

6. Turner, B.L.; Papházy, M.J.; Haygarth, P.M.; McKelvie, I.D. Inositol phosphates in the environment. Philos. Trans. R. Soc. B Biol. Sci. 2002, 357, 449-469. [CrossRef] [PubMed]

7. Stewart, J.W.B.; Tiessen, H. Dynamics of soil organic phosphorus. Biogeochemistry 1987, 4, 41-60. [CrossRef]

8. Cade-Menun, B.J.; Carter, M.R.; James, D.C.; Liu, C.W. Phosphorus forms and chemistry in the soil profile under long-term conservation tillage: A phosphorus-31 nuclear magnetic resonance study. J. Environ. Qual. 2010, 39, 1647-1656. [CrossRef]

9. Ha, S.; Tran, L.-S. Understanding plant responses to phosphorus starvation for improvement of plant tolerance to phosphorus deficiency by biotechnological approaches. Crit. Rev. Biotechnol. 2014, 34, 16-30. [CrossRef]

10. Laliberté, E.; Turner, B.L.; Costes, T.; Pearse, S.J.; Wyrwoll, K.-H.; Zemunik, G.; Lambers, H. Experimental assessment of nutrient limitation along a 2-million-year dune chronosequence in the south-western Australia biodiversity hotspot. J. Ecol. 2012, 100, 631-642. [CrossRef]

11. Kouas, S.; Labidi, N.; Debez, A.; Abdelly, C. Effect of P on nodule formation and N fixation in bean. Agron. Sustain. Dev. 2005, 25, 389-393. [CrossRef]

12. Vance, C.P.; Uhde-Stone, C.; Allan, D.L. Phosphorus acquisition and use: Critical adaptations by plants for securing a nonrenewable resource. New Phytol. 2003, 157, 423-447. [CrossRef]

13. Bieleski, R.L. Phosphate pools, phosphate transport, and phosphate availability. Annu. Rev. Plant Physiol. 1973, 24, 225-252. [CrossRef]

14. Jain, A.; Poling, M.D.; Karthikeyan, A.S.; Blakeslee, J.J.; Peer, W.A.; Titapiwatanakun, B.; Murphy, A.S.; Raghothama, K.G. Differential effects of sucrose and auxin on localized phosphate deficiency-induced modulation of different traits of root system architecture in Arabidopsis. Plant Physiol. 2007, 144, 232-247. [CrossRef] [PubMed]

15. Chacón-López, A.; Cruz-Ramírez, A.; Nieto-Jacobo, F.; Sánchez-Calderón, L.; Herrera-Estrella, L.; López-Bucio, J.; Dubrovsky, J.G. Phosphate starvation induces a determinate developmental program in the roots of Arabidopsis thaliana. Plant Cell Physiol. 2005, 46, 174-184.

16. Carvalho, F.P. Agriculture, pesticides, food security and food safety. Environ. Sci. Policy 2006, 9, 685-692. [CrossRef]

17. Gyaneshwar, P.; Naresh Kumar, G.; Parekh, L.J.; Poole, P.S. Role of soil microorganisms in improving P nutrition of plants. Plant Soil 2002, 245, 83-93. [CrossRef]

18. King, K.W.; Williams, M.R.; Macrae, M.L.; Fausey, N.R.; Frankenberger, J.; Smith, D.R.; Kleinman, P.J.A.; Brown, L.C. Phosphorus transport in agricultural subsurface drainage: A review. J. Environ. Qual. 2015, 44, 467-485. [CrossRef]

19. Cordell, D.; Drangert, J.O.; White, S. The story of phosphorus: Global food security and food for thought. Glob. Environ. Change 2009, 19, 292-305. [CrossRef]

20. Dhillon, J.; Torres, G.; Driver, E.; Figueiredo, B.; Raun, W.R. World phosphorus use efficiency in cereal crops. Agron. J. 2017, 109, 1670-1677. [CrossRef]

21. Rutherford, P.M.; Dudas, M.J.; Arocena, J.M. Trace elements and fluoride in phosphogypsum leachates. Environ. Technol. 1995, 16, 343-354. [CrossRef]

22. Garcia, K.; Delaux, P.-M.; Cope, K.R.; Ané, J.-M. Molecular signals required for the establishment and maintenance of ectomycorrhizal symbioses. New Phytol. 2015, 208, 79-87. [CrossRef] [PubMed] 
23. Duff, S.M.G.; Sarath, G.; Plaxton, W.C. The role of acid phosphatases in plant phosphorus metabolism. Physiol. Plant. 1994, 90, 791-800. [CrossRef]

24. Jones, D.L. Organic acids in the rhizosphere-A critical review. Plant Soil 1998, 205, 25-44. [CrossRef]

25. Giehl, R.F.H.; von Wiren, N. Root nutrient foraging. Plant Physiol. 2014, 166, 509-517. [CrossRef] [PubMed]

26. Raven, J.A.; Lambers, H.; Smith, S.E.; Westoby, M. Costs of acquiring phosphorus by vascular land plants: Patterns and implications for plant coexistence. New Phytol. 2018, 217, 1420-1427. [CrossRef] [PubMed]

27. Kraus, M.; Fusseder, A.; Beck, E. Development and replenishment of the P-depletion zone around the primary root of maize during the vegetation period. Plant Soil 1987, 101, 247-255. [CrossRef]

28. Smith, S.E.; Anderson, I.C.; Smith, F.A. Mycorrhizal associations and phosphorus acquisition: From cells to ecosystems. Annu. Plant Rev. 2015, 48, 409-439.

29. Bates, T.R.; Lynch, J.P. Stimulation of root hair elongation in Arabidopsis thaliana by low phosphorus availability. Plant Cell Environ. 1996, 19, 529-538. [CrossRef]

30. Rausch, C.; Bucher, M. Molecular mechanisms of phosphate transport in plants. Planta 2002, 216, 23-37. [CrossRef]

31. Sawers, R.J.H.; Svane, S.F.; Quan, C.; Grønlund, M.; Wozniak, B.; Gebreselassie, M.-N.; González-Muñoz, E.; Chávez Montes, R.A.; Baxter, I.; Goudet, J.; et al. Phosphorus acquisition efficiency in arbuscular mycorrhizal maize is correlated with the abundance of root-external hyphae and the accumulation of transcripts encoding PHT1 phosphate transporters. New Phytol. 2017, 214, 632-643. [CrossRef]

32. Smith, S.E.; Smith, F.A. Roles of arbuscular mycorrhizas in plant nutrition and growth: New paradigms from cellular to ecosystem scales. Annu. Rev. Plant Biol. 2011, 62, 227-250. [CrossRef] [PubMed]

33. Wang, B.; Qiu, Y.-L. Phylogenetic distribution and evolution of mycorrhizas in land plants. Mycorrhiza 2006, 16, 299-363. [CrossRef] [PubMed]

34. Brundrett, M.C.; Tedersoo, L. Evolutionary history of mycorrhizal symbioses and global host plant diversity. New Phytol. 2018, 220, 1108-1115. [CrossRef] [PubMed]

35. Vigneron, N.; Radhakrishnan, G.V.; Delaux, P.M. What have we learnt from studying the evolution of the arbuscular mycorrhizal symbiosis? Curr. Opin. Plant Biol. 2018, 44, 49-56. [CrossRef] [PubMed]

36. Sepp, S.K.; Davison, J.; Jairus, T.; Vasar, M.; Moora, M.; Zobel, M.; Öpik, M. Non-random association patterns in a plant-mycorrhizal fungal network reveal host-symbiont specificity. Mol. Ecol. 2019, 28, 365-378. [CrossRef] [PubMed]

37. Timonen, S.; Marschner, P. Mycorrhizosphere concept. In Microbial Activity in the Rhizoshere; Mukerji, K.G., Manoharachary, C., Singh, J., Eds.; Springer: Berlin/Heidelberg, Germany, 2006; pp. 155-172. ISBN 978-3-540-29420-7.

38. Priyadharsini, P.; Rojamala, K.; Ravi, R.K.; Muthuraja, R.; Nagaraj, K.; Muthukumar, T. Mycorrhizosphere: The extended rhizosphere and its significance. In Plant-Microbe Interaction: An Approach to Sustainable Agriculture; Choudhary, D.K., Varma, A., Tuteja, N., Eds.; Springer: Singapore, 2016; pp. 97-124. ISBN 978-981-10-2854-0.

39. Harrison, M.J. Signaling in the arbuscular mycorrhizal symbiosis. Annu. Rev. Microbiol. 2005, 59, $19-42$. [CrossRef] [PubMed]

40. Breuillin-Sessoms, F.; Floss, D.S.; Gomez, S.K.; Pumplin, N.; Ding, Y.; Levesque-Tremblay, V.; Noar, R.D.; Daniels, D.A.; Bravo, A.; Eaglesham, J.B.; et al. Suppression of arbuscule degeneration in Medicago truncatula phosphate transporter4 mutants is dependent on the ammonium transporter 2 family protein AMT2;3. Plant Cell 2015, 27, 1352-1366. [CrossRef] [PubMed]

41. Baier, M.C.; Keck, M.; Gödde, V.; Niehaus, K.; Küster, H.; Hohnjec, N. Knockdown of the symbiotic sucrose synthase MtSucS1 affects arbuscule maturation and maintenance in mycorrhizal roots of Medicago truncatula. Plant Physiol. 2010, 152, 1000-1014. [CrossRef]

42. Kiers, E.T.; Duhamel, M.; Beesetty, Y.; Mensah, J.; Franken, O.; Verbruggen, E.; Fellbaum, C.R.; Kowalchuk, G.; Hart, M.M.; Bago, A.; et al. Reciprocal rewards stabilize cooperation in the mycorrhizal symbiosis. Science 2011, 333, 880-882. [CrossRef]

43. Luginbuehl, L.H.; Menard, G.N.; Kurup, S.; Van Erp, H.; Radhakrishnan, G.V.; Breakspear, A.; Oldroyd, G.E.D.; Eastmond, P.J. Fatty acids in arbuscular mycorrhizal fungi are synthesized by the host plant. Science 2017, 356, 1175-1178. [CrossRef] 
44. Bravo, A.; Brands, M.; Wewer, V.; Dörmann, P.; Harrison, M.J. Arbuscular mycorrhiza-specific enzymes FatM and RAM2 fine-tune lipid biosynthesis to promote development of arbuscular mycorrhiza. New Phytol. 2017, 214, 1631-1645. [CrossRef]

45. Zheng, C.; Ji, B.; Zhang, J.; Zhang, F.; Bever, J.D. Shading decreases plant carbon preferential allocation towards the most beneficial mycorrhizal mutualist. New Phytol. 2015, 205, 361-368. [CrossRef] [PubMed]

46. Lendenmann, M.; Thonar, C.; Barnard, R.L.; Salmon, Y.; Werner, R.A.; Frossard, E.; Jansa, J. Symbiont identity matters: Carbon and phosphorus fluxes between Medicago truncatula and different arbuscular mycorrhizal fungi. Mycorrhiza 2011, 21, 689-702. [CrossRef] [PubMed]

47. Garcia, K.; Doidy, J.; Zimmermann, S.D.; Wipf, D.; Courty, P.-E. Take a trip through the plant and fungal transportome of mycorrhiza. Trends Plant Sci. 2016, 21, 937-950. [CrossRef] [PubMed]

48. Smith, S.E.; Read, D. Mycorrhizal Symbiosis, 3rd ed.; Academic Press: London, UK, 2008; ISBN 978-0-12-370526-6.

49. Guerrero-Galán, C.; Houdinet, G.; Calvo-Polanco, M.; Bonaldi, K.E.; Garcia, K.; Zimmermann, S.D. The role of plant transporters in mycorrhizal symbioses. Adv. Bot. Res. 2018, 87, 303-342.

50. Paszkowski, U.; Kroken, S.; Roux, C.; Briggs, S.P. Rice phosphate transporters include an evolutionarily divergent gene specifically activated in arbuscular mycorrhizal symbiosis. Proc. Natl. Acad. Sci. USA 2002, 99, 13324-13329. [CrossRef] [PubMed]

51. Rausch, C.; Daram, P.; Brunner, S.; Jansa, J.; Laloi, M.; Leggewie, G.; Amrhein, N.; Bucher, M. A phosphate transporter expressed in arbuscule-containing cells in potato. Nature 2001, 414, 462-470. [CrossRef] [PubMed]

52. Afkhami, M.E.; Stinchcombe, J.R. Multiple mutualist effects on genomewide expression in the tripartite association between Medicago truncatula, nitrogen-fixing bacteria and mycorrhizal fungi. Mol. Ecol. 2016, 25, 4946-4962. [CrossRef]

53. Kafle, A.; Garcia, K.; Wang, X.; Pfeffer, P.E.; Strahan, G.D.; Bücking, H. Nutrient demand and fungal access to resources control the carbon allocation to the symbiotic partners in tripartite interactions of Medicago truncatula. Plant Cell Environ. 2019, 42, 270-284. [CrossRef]

54. Ossler, J.N.; Zielinski, C.A.; Heath, K.D. Tripartite mutualism: Facilitation or trade-offs between rhizobial and mycorrhizal symbionts of legume hosts. Am. J. Bot. 2015, 102, 1332-1341. [CrossRef]

55. Desbrosses, G.J.; Stougaard, J. Root nodulation: A Paradigm for how plant-microbe symbiosis influences host developmental pathways. Cell Host Microbe 2011, 10, 348-358. [CrossRef] [PubMed]

56. Paul, E.A.; Kucey, R.M.N. Carbon flow in plant microbial associations. Science 1981, 213, 473-474. [CrossRef] [PubMed]

57. Herridge, D.F.; Peoples, M.B.; Boddey, R.M. Global inputs of biological nitrogen fixation in agricultural systems. Plant Soil 2008, 311, 1-18. [CrossRef]

58. Liu, J.; Ma, K.; Ciais, P.; Polasky, S. Reducing human nitrogen use for food production. Sci. Rep. 2016, 6, 30104. [CrossRef] [PubMed]

59. Udvardi, M.; Poole, P.S. Transport and metabolism in legume-rhizobia symbioses. Annu. Rev. Plant Biol. 2013, 64, 781-805. [CrossRef] [PubMed]

60. Sulieman, S.; Schulze, J.; Tran, L.-S.P. Comparative analysis of the symbiotic efficiency of Medicago truncatula and Medicago sativa under phosphorus deficiency. Int. J. Mol. Sci. 2013, 14, 5198-5213. [CrossRef] [PubMed]

61. Schulze, J. How are nitrogen fixation rates regulated in legumes? J. Plant Nutr. Soil Sci. 2004, 167, $125-137$. [CrossRef]

62. Sulieman, S.; Van Ha, C.; Schulze, J.; Tran, L.-S.P. Growth and nodulation of symbiotic Medicago truncatula at different levels of phosphorus availability. J. Exp. Bot. 2013, 64, 2701-2712. [CrossRef]

63. Thuita, M.; Vanlauwe, B.; Mutegi, E.; Masso, C. Reducing spatial variability of soybean response to rhizobia inoculants in farms of variable soil fertility in Siaya County of western Kenya. Agric. Ecosyst. Environ. 2018, 261, 153-160. [CrossRef]

64. Ulzen, J.; Abaidoo, R.C.; Ewusi-Mensah, N.; Masso, C. On-farm evaluation and determination of sources of variability of soybean response to Bradyrhizobium inoculation and phosphorus fertilizer in northern Ghana. Agric. Ecosyst. Environ. 2018, 267, 23-32. [CrossRef]

65. Bournaud, C.; James, E.K.; de Faria, S.M.; Lebrun, M.; Melkonian, R.; Duponnois, R.; Tisseyre, P.; Moulin, L.; Prin, Y. Interdependency of efficient nodulation and arbuscular mycorrhization in Piptadenia gonoacantha, a Brazilian legume tree. Plant Cell Environ. 2018, 41, 2008-2020. [CrossRef] [PubMed] 
66. Püschel, D.; Janoušková, M.; Vořǐšková, A.; Gryndlerová, H.; Vosátka, M.; Jansa, J. Arbuscular mycorrhiza stimulates biological nitrogen fixation in two Medicago spp. through improved phosphorus acquisition. Front. Plant Sci. 2017, 8, 390. [CrossRef] [PubMed]

67. Wang, X.; Pan, Q.; Chen, F.; Yan, X.; Liao, H. Effects of co-inoculation with arbuscular mycorrhizal fungi and rhizobia on soybean growth as related to root architecture and availability of N and P. Mycorrhiza 2011, 21, 173-181. [CrossRef] [PubMed]

68. Ibiang, Y.B.; Mitsumoto, H.; Sakamoto, K. Bradyrhizobia and arbuscular mycorrhizal fungi modulate manganese, iron, phosphorus, and polyphenols in soybean (Glycine max (L.) Merr.) under excess zinc. Environ. Exp. Bot. 2017, 137, 1-13. [CrossRef]

69. Kaschuk, G.; Kuyper, T.W.; Leffelaar, P.A.; Hungria, M.; Giller, K.E. Are the rates of photosynthesis stimulated by the carbon sink strength of rhizobial and arbuscular mycorrhizal symbioses? Soil Biol. Biochem. 2009, 41, 1233-1244. [CrossRef]

70. Mortimer, P.E.; Le Roux, M.R.; Pérez-Fernández, M.A.; Benedito, V.A.; Kleinert, A.; Xu, J.; Valentine, A.J. The dual symbiosis between arbuscular mycorrhiza and nitrogen fixing bacteria benefits the growth and nutrition of the woody invasive legume Acacia cyclops under nutrient limiting conditions. Plant Soil 2013, 366, 229-241. [CrossRef]

71. Eulenstein, F.; Tauschke, M.; Behrendt, A.; Monk, J.; Schindler, U.; Lana, A.M.; Monk, S. The application of mycorrhizal fungi and organic fertilisers in horticultural potting soils to improve water use efficiency of crops. Horticulturae 2017, 3, 8. [CrossRef]

72. Ortas, I. The effect of mycorrhizal fungal inoculation on plant yield, nutrient uptake and inoculation effectiveness under long-term field conditions. Fields Crops Res. 2012, 125, 35-48. [CrossRef]

73. Cely, M.V.T.; de Oliveira, A.G.; de Freitas, V.F.; de Luca, M.B.; Barazetti, A.R.; dos Santos, I.M.O.; Gionco, B.; Garcia, G.V.; Prete, C.E.C.; Andrade, G. Inoculant of arbuscular mycorrhizal fungi (Rhizophagus clarus) increase yield of soybean and cotton under field conditions. Front. Microbiol. 2016, 7, 720. [CrossRef] [PubMed]

74. Mahanta, D.; Rai, R.K.; Mishra, S.D.; Raja, A.; Purakayastha, T.J.; Varghese, E. Influence of phosphorus and biofertilizers on soybean and wheat root growth and properties. Field Crops Res. 2014, 166, 1-9. [CrossRef]

75. Niwa, R.; Koyama, T.; Sato, T.; Adachi, K.; Tawaraya, K.; Sato, S.; Hirakawa, H.; Yoshida, S.; Ezawa, T. Dissection of niche competition between introduced and indigenous arbuscular mycorrhizal fungi with respect to soybean yield responses. Sci. Rep. 2018, 8, 7419. [CrossRef] [PubMed]

76. Verbruggen, E.; Heijden, M.G.A.; Rillig, M.C.; Kiers, T.E. Mycorrhizal fungal establishment in agricultural soils: Factors determining inoculation success. New Phytol. 2012, 197, 1104-1109. [CrossRef]

77. Ryan, M.H.; Graham, J.H. Little evidence that farmers should consider abundance or diversity of arbuscular mycorrhizal fungi when managing crops. New Phytol. 2018, 220, 1092-1107. [CrossRef] [PubMed]

78. Ryan, M.H.; Graham, J.H.; Morton, J.B.; Kirkegaard, J.A. Research must use a systems agronomy approach if management of the arbuscular mycorrhizal symbiosis is to contribute to sustainable intensification. New Phytol. 2019. Available online: https://nph.onlinelibrary.wiley.com/doi/10.1111/nph.15600 (accessed on 18 January 2019). [CrossRef] [PubMed]

79. Rillig, M.C.; Aguilar-Trigueros, C.A.; Camenzind, T.; Cavagnaro, T.R.; Degrune, F.; Hohmann, P.; Lammel, D.R.; Mansour, I.; Roy, J.; van der Heijden, M.G.A.; et al. Why farmers should manage the arbuscular mycorrhizal symbiosis. New Phytol. 2019. Available online: https://nph.onlinelibrary.wiley.com/ doi/10.1111/nph.15602 (accessed on 18 January 2019).

80. Wang, X.; Zhao, S.; Bücking, H. Arbuscular mycorrhizal growth responses are fungal specific but do not differ between soybean genotypes with different phosphate efficiency. Ann. Bot. 2016, 118, 11-21. [CrossRef] [PubMed]

81. Li, H.; Smith, F.A.; Dickson, S.; Holloway, R.E.; Smith, S.E. Plant growth depressions in arbuscular mycorrhizal symbioses: Not just caused by carbon drain? New Phytol. 2008, 178, 852-862. [CrossRef] [PubMed]

82. Mäder, P.; Kaiser, F.; Adholeya, A.; Singh, R.; Uppal, H.S.; Sharma, A.K.; Srivastava, R.; Sahai, V.; Aragno, M.; Wiemken, A.; et al. Inoculation of root microorganisms for sustainable wheat-rice and wheat-black gram rotations in India. Soil Biol. Biochem. 2011, 43, 609-619. [CrossRef]

83. Somerville, C.; Youngs, H.; Taylor, C.; Davis, S.C.; Long, S.P. Feedstocks for lignocellulosic biofuels. Science 2010, 329, 790-792. [CrossRef] [PubMed] 
84. Guo, M.; Song, W.; Buhain, J. Bioenergy and biofuels: History, status, and perspective. Renew. Sustain. Energy Rev. 2015, 42, 712-725. [CrossRef]

85. Guo, M.; Li, C.; Facciotto, G.; Bergante, S.; Bhatia, R.; Comolli, R.; Ferré, C.; Murphy, R. Bioethanol from poplar clone Imola: An environmentally viable alternative to fossil fuel? Biotechnol. Biofuels 2015, 8, 134. [CrossRef]

86. Macaya-Sanz, D.; Chen, J.; Kalluri, U.C.; Muchero, W.; Tschaplinski, T.J.; Gunter, L.E.; Simon, S.J.; Biswal, A.K.; Bryan, A.C.; Payyavula, R.; et al. Agronomic performance of Populus deltoides trees engineered for biofuel production. Biotechnol. Biofuels 2017, 10, 253. [CrossRef] [PubMed]

87. Richards, B.K.; Stoof, C.R.; Cary, I.J.; Woodbury, P.B. Reporting on marginal lands for bioenergy feedstock production: A modest proposal. BioEnergy Res. 2014, 7, 1060-1062. [CrossRef]

88. Altieri, M.A. Agroecology: The science of natural resource management for poor farmers in marginal environments. Agric. Ecosyst. Environ. 2002, 93, 1-24. [CrossRef]

89. Mitchell, C. New cultural treatments and yield optimisation. Biomass Bioenergy 1995, 9, 11-34. [CrossRef]

90. Guénon, R.; Bastien, J.-C.; Thiébeau, P.; Bodineau, G.; Bertrand, I. Carbon and nutrient dynamics in short-rotation coppice of poplar and willow in a converted marginal land, a case study in central France. Nutr. Cycl. Agroecosyst. 2016, 106, 293-309. [CrossRef]

91. Becquer, A.; Guerrero-Galán, C.; Eibensteiner, J.L.; Houdinet, G.; Bücking, H.; Zimmermann, S.D.; Garcia, K. The ectomycorrhizal contribution to tree nutrition. Adv. Bot. Res. 2019, 89, 77-126.

92. Spatafora, J.W.; Chang, Y.; Benny, G.L.; Lazarus, K.; Smith, M.E.; Berbee, M.L.; Bonito, G.; Corradi, N.; Grigoriev, I.; Gryganskyi, A.; et al. A phylum-level phylogenetic classification of zygomycete fungi based on genome-scale data. Mycologia 2017, 108, 1028-1046. [CrossRef]

93. Spatafora, J.W.; Aime, M.C.; Grigoriev, I.V.; Martin, F.; Stajich, J.E.; Blackwell, M. The fungal tree of life: From molecular systematics to genome-scale phylogenies. Microbiol. Spectr. 2017, 5. Available online: http: / / www.asmscience.org/content/journal/microbiolspec/10.1128/microbiolspec.FUNK-0053-2016 (accessed on 15 September 2017). [CrossRef]

94. Pan, Y.; Birdsey, R.A.; Phillips, O.L.; Jackson, R.B. The structure, distribution, and biomass of the world's forests. Annu. Rev. Ecol. Evol. Syst. 2013, 44, 593-622. [CrossRef]

95. Martin, F.; Duplessis, S.; Ditengou, F.; Lagrange, H.; Voiblet, C.; Lapeyrie, F. Developmental cross talking in the ectomycorrhizal symbiosis: Signals and communication genes. New Phytol. 2001, 151, 145-154. [CrossRef]

96. Clemmensen, K.E.; Bahr, A.; Ovaskainen, O.; Dahlberg, A.; Ekblad, A.; Wallander, H.; Stenlid, J.; Finlay, R.D.; Wardle, D.; Lindahl, B.D. Roots and associated fungi drive long-term carbon sequestration in boreal forest. Science 2013, 339, 1615-1618. [CrossRef] [PubMed]

97. Marmeisse, R.; Girlanda, M. Mycorrhizal fungi and the soil carbon and nutrient cycling. In Environmental and Microbial Relationships; Druzhinina, I.S., Kubicek, C.P., Eds.; Springer International Publishing: Cham, Switzerland, 2016; pp. 189-203. ISBN 978-3-319-29532-9.

98. Tatry, M.-V.; El Kassis, E.; Lambilliotte, R.; Corratgé, C.; van Aarle, I.; Amenc, L.K.; Alary, R.; Zimmermann, S.; Sentenac, H.; Plassard, C. Two differentially regulated phosphate transporters from the symbiotic fungus Hebeloma cylindrosporum and phosphorus acquisition by ectomycorrhizal Pinus pinaster. Plant J. 2009, 57, 1092-1102. [CrossRef] [PubMed]

99. Garcia, K.; Haider, M.Z.; Delteil, A.; Corratgé-Faillie, C.; Conéjero, G.; Tatry, M.-V.; Becquer, A.; Amenc, L.; Sentenac, H.; Plassard, C.; et al. Promoter-dependent expression of the fungal transporter HcPT1.1 under Pi shortage and its spatial localization in ectomycorrhiza. Fungal Genet. Biol. 2013, 58-59, 53-61. [CrossRef] [PubMed]

100. Becquer, A.; Garcia, K.; Plassard, C. HcPT1.2 participates in Pi acquisition in Hebeloma cylindrosporum external hyphae of ectomycorrhizas under high and low phosphate conditions. Plant Signal Behav. 2018, 13, e1525997. [CrossRef] [PubMed]

101. Torres-Aquino, M.; Becquer, A.; Le Guernevé, C.; Louche, J.; Amenc, L.K.; Staunton, S.; Quiquampoix, H.; Plassard, C. The host plant Pinus pinaster exerts specific effects on phosphate efflux and polyphosphate metabolism of the ectomycorrhizal fungus Hebeloma cylindrosporum: A radiotracer, cytological staining and 31P NMR spectroscopy study. Plant Cell Environ. 2017, 40, 190-202. [CrossRef] [PubMed]

102. Becquer, A.; Garcia, K.; Amenc, L.; Rivard, C.; Doré, J.; Trives-Segura, C.; Szponarski, W.; Russet, S.; Baeza, Y.; Lassalle-Kaiser, B.; et al. The Hebeloma cylindrosporum HcPT2 Pi transporter plays a key role in ectomycorrhizal symbiosis. New Phytol. 2018, 220, 1185-1199. [CrossRef] 
103. Loth-Pereda, V.; Orsini, E.; Courty, P.-E.; Lota, F.; Kohler, A.; Diss, L.; Blaudez, D.; Chalot, M.; Nehls, U.; Bucher, M.; et al. Structure and expression profile of the phosphate Pht1 transporter gene family in mycorrhizal Populus trichocarpa. Plant Physiol. 2011, 156, 2141-2154. [CrossRef]

104. Rousseau, J.V.D.; Sylvia, D.M.; Fox, A.J. Contribution of ectomycorrhiza to the potential nutrient-absorbing surface of pine. New Phytol. 1994, 128, 639-644. [CrossRef]

105. Torres Aquino, M.; Plassard, C. Dynamics of ectomycorrhizal mycelial growth and P transfer to the host plant in response to low and high soil P availability. FEMS Microbiol. Ecol. 2004, 48, 149-156. [CrossRef]

106. Chen, W.; Koide, R.T.; Adams, T.S.; DeForest, J.L.; Cheng, L.; Eissenstat, D.M. Root morphology and mycorrhizal symbioses together shape nutrient foraging strategies of temperate trees. Proc. Nalt. Acad. Sci. USA 2016, 113, 8741-8746. [CrossRef]

107. Brandes, B.; Godbold, D.L.; Kuhn, A.J.; Jentschke, G. Nitrogen and phosphorus acquisition by the mycelium of the ectomycorrhizal fungus Paxillus involutus and its effect on host nutrition. New Phytol. 1998, 140, 735-743. [CrossRef]

108. Jentschke, G.; Brandes, B.; Kuhn, A.J.; Schröder, W.H.; Godbold, D.L. Interdependence of phosphorus, nitrogen, potassium and magnesium translocation by the ectomycorrhizal fungus Paxillus involutus. New Phytol. 2001, 149, 327-337. [CrossRef]

109. Colpaert, J.V.; Van Tichelen, K.K.; Van Assche, J.A.; Van Laere, A. Short-term phosphorus uptake rates in mycorrhizal and non-mycorrhizal roots of intact Pinus sylvestris seedlings. New Phytol. 1999, 143, 589-597. [CrossRef]

110. Jones, M.D.; Durall, D.M.; Tinker, P.B. A comparison of arbuscular and ectomycorrhizal Eucalyptus coccifera: Growth response, phosphorus uptake efficiency and external hyphal production. New Phytol. 1998, 140, 125-134. [CrossRef]

111. Van Tichelen, K.K.; Colpaert, V.J. Kinetics of phosphate absorption by mycorrhizal and non-mycorrhizal Scots pine seedlings. Physiol. Plant. 2000, 110, 96-103. [CrossRef]

112. Plassard, C.; Louche, J.; Ali, M.A.; Duchemin, M.; Legname, E.; Cloutier-Hurteau, B. Diversity in phosphorus mobilisation and uptake in ectomycorrhizal fungi. Ann. For. Sci. 2011, 68, 33-43. [CrossRef]

113. Rineau, F.; Shah, F.; Smits, M.M.; Persson, P.; Johansson, T.; Carleer, R.; Troein, C.; Tunlid, A. Carbon availability triggers the decomposition of plant litter and assimilation of nitrogen by an ectomycorrhizal fungus. ISME J. 2013, 7, 2010-2022. [CrossRef] [PubMed]

114. Tunlid, A.; Floudas, D.; Koide, R.; Rineau, F. Soil organic matter decomposition mechanisms in ectomycorrhizal fungi. In Molecular Mycorrhizal Symbiosis; Wiley-Blackwell: Hoboken, NJ, USA, 2016; pp. 257-275. ISBN 9781118951446.

115. Antibus, R.K.; Sinsabaugh, R.L.; Linkins, A.E. Phosphatase activities and phosphorus uptake from inositol phosphate by ectomycorrhizal fungi. Can. J. Bot. 1992, 70, 794-801. [CrossRef]

116. Colpaert, J.V.; Van Laere, A.; Van Tichelen, K.K.; Van Assche, J.A. The use of inositol hexaphosphate as a phosphorus source by mycorrhizal and non-mycorrhizal Scots Pine (Pinus sylvestris). Funct. Ecol. 1997, 11, 407-415. [CrossRef]

117. Perez-Moreno, J.; Read, J.D. Mobilization and transfer of nutrients from litter to tree seedlings via the vegetative mycelium of ectomycorrhizal plants. New Phytol. 2000, 145, 301-309. [CrossRef]

118. Perez-Moreno, J.; Read, D.J. Exploitation of pollen by mycorrhizal mycelial systems with special reference to nutrient recycling in boreal forests. Proc. Biol. Sci. 2001, 268, 1329-1335. [CrossRef] [PubMed]

119. Perez-Moreno, J.; Read, D.J. Nutrient transfer from soil nematodes to plants: A direct pathway provided by the mycorrhizal mycelial network. Plant Cell Environ. 2002, 24, 1219-1226. [CrossRef]

120. Tibbett, M.; Sanders, F.E. Ectomycorrhizal symbiosis can enhance plant nutrition through improved access to discrete organic nutrient patches of high resource quality. Ann. Bot. 2002, 89, 783-789. [CrossRef] [PubMed]

121. Lindahl, B.; Stenlid, J.; Olsson, S.; Finlay, R. Translocation of 32P between interacting mycelia of a wood-decomposing fungus and ectomycorrhizal fungi in microcosm systems. New Phytol. 1999, 144, 183-193. [CrossRef]

122. Fontaine, L.; Thiffault, N.; Paré, D.; Fortin, J.-A.; Piché, Y. Phosphate-solubilizing bacteria isolated from ectomycorrhizal mycelium of Picea glauca are highly efficient at fluorapatite weathering. Botany 2016, 94, 1183-1193. [CrossRef]

123. Trappe, J.M. Selection of fungi for ectomycorrhizal inoculation in nurseries. Annu. Rev. Phytopathol. 1977, 15, 203-222. [CrossRef] 
124. Marx, D.H. Ectomycorrhizal fungus inoculations: A tool for improving forestation practices. Trop. Mycorrhiza Res. 1980, 118, 13-71.

125. Sharma, S.B.; Sayyed, R.Z.; Trivedi, M.H.; Gobi, T.A. Phosphate solubilizing microbes: Sustainable approach for managing phosphorus deficiency in agricultural soils. Springerplus 2013, 2, 587. [CrossRef]

126. Banik, S.; Dey, B.K. Available phosphate content of an alluvial soil as influenced by inoculation of some isolated phosphate-solubilizing micro-organisms. Plant Soil 1982, 69, 353-364. [CrossRef]

127. Banik, S.; Dey, B.K. Phosphate-solubilizing potentiality of the microorganisms capable of utilizing aluminium phosphate as a sole phosphate source. Zent. Mikrobiol. 1983, 138, 17-23. [CrossRef]

128. Gupta, R.; Singal, R.; Shankar, A.; Kuhad, R.C.; Saxena, R.K. A modified plate assay for screening phosphate solubilizing microorganisms. J. Gen. Appl. Microbiol. 1994, 40, 255-260. [CrossRef]

129. Vazquez, P.; Holguin, G.; Puente, M.E.; Lopez-Cortes, A.; Bashan, Y. Phosphate-solubilizing microorganisms associated with the rhizosphere of mangroves in a semiarid coastal lagoon. Biol. Fertil. Soils 2000, 30, 460-468. [CrossRef]

130. Sadiq, H.M.; Jahangir, G.Z.; Nasir, I.A.; Iqtidar, M.; Iqbal, M. Isolation and characterization of phosphatesolubilizing bacteria from rhizosphere soil. Biotechnol. Biotechnol. Equip. 2013, 27, 4248-4255. [CrossRef]

131. Tani, A.; Akita, M.; Murase, H.; Kimbara, K. Culturable bacteria in hydroponic cultures of moss Racomitrium japonicum and their potential as biofertilizers for moss production. J. Biosci. Bioeng. 2011, 112, 32-39. [CrossRef]

132. Bar-Yosef, B.; Rogers, R.D.; Wolfram, J.H.; Richman, E. Pseudomonas cepacia-Mediated rock phosphate solubilization in kaolinite and montmorillonite suspensions contribution from the agricultural research organization series 626/98. Soil Sci. Soc. Am. J. 1999, 63, 1703-1708. [CrossRef]

133. Yi, Y.; Huang, W.; Ge, Y. Exopolysaccharide: A novel important factor in the microbial dissolution of tricalcium phosphate. World J. Microbiol. Biotechnol. 2008, 24, 1059-1065. [CrossRef]

134. Hwangbo, H.; Park, R.D.; Kim, Y.W.; Rim, Y.S.; Park, K.H.; Kim, T.H.; Suh, J.S.; Kim, K.Y. 2-Ketogluconic acid production and phosphate solubilization by Enterobacter intermedium. Curr. Microbiol. 2003, 47, 87-92.

135. Shahid, M.; Hameed, S.; Imran, A.; Ali, S.; van Elsas, J.D. Root colonization and growth promotion of sunflower (Helianthus annuus L.) by phosphate solubilizing Enterobacter sp. Fs-11. World J. Microbiol. Biotechnol. 2012, 28, 2749-2758. [CrossRef]

136. Thaller, M.C.; Berlutti, F.; Schippa, S.; Iori, P.; Passariello, C.; Rossolini, G.M. Heterogeneous patterns of acid phosphatases containing low-molecular-mass polypeptides in members of the family Enterobacteriaceae. Int. J. Syst. Evol. Microbiol. 1995, 45, 255-261. [CrossRef]

137. Ohtake, H.; Wu, H.; Imazu, K.; Anbe, Y.; Kato, J.; Kuroda, A. Bacterial phosphonate degradation, phosphite oxidation and polyphosphate accumulation. Resour. Conserv. Recycl. 1996, 18, 125-134. [CrossRef]

138. Katznelson, H.; Bose, B. Metabolic activity and phosphate-dissolving capability of bacterial isolates from wheat roots, rhizosphere, and non-rhizosphere soil. Can. J. Microbiol. 1959, 5, 79-85. [CrossRef] [PubMed]

139. Halder, A.K.; Chakrabartty, P.K. Solubilization of inorganic phosphate by Rhizobium. Folia Microbiol. 1993, 38, 325-330. [CrossRef]

140. Bajpai, P.D.; Sundara Rao, W.V.B. Phosphate solubilising bacteria. Soil Sci. Plant Nutr. 1971, 17, 44-45. [CrossRef]

141. Gyaneshwar, P.; Kumar, G.N.; Parekh, L.J. Effect of buffering on the phosphate-solubilizing ability of microorganisms. World J. Microbiol. Biotechnol. 1998, 14, 669-673. [CrossRef]

142. Kirk, G.J.D.; Santos, E.E.; Findenegg, G.R. Phosphate solubilization by organic anion excretion from rice (Oryza sativa L.) growing in aerobic soil. Plant Soil 1999, 211, 11-18. [CrossRef]

143. Jiang, H.; Qi, P.; Wang, T.; Wang, M.; Chen, M.; Chen, N.; Pan, L.; Chi, X. Isolation and characterization of halotolerant phosphate-solubilizing microorganisms from saline soils. 3 Biotech 2018, 8, 461. [CrossRef]

144. Park, K.-H.; Lee, C.-Y.; Son, H.-J. Mechanism of insoluble phosphate solubilization by Pseudomonas fluorescens RAF15 isolated from ginseng rhizosphere and its plant growth-promoting activities. Lett. Appl. Microbiol. 2009, 49, 222-228. [CrossRef]

145. Kim, K.Y.; McDonald, G.A.; Jordan, D. Solubilization of hydroxyapatite by Enterobacter agglomerans and cloned Escherichia coli in culture medium. Biol. Fertil. Soils 1997, 24, 347-352. [CrossRef]

146. Ragot, S.A.; Kertesz, M.A.; Mészáros, É.; Frossard, E.; Bünemann, E.K. Soil phoD and phoX alkaline phosphatase gene diversity responds to multiple environmental factors. FEMS Microbiol. Ecol. 2016, 93, fiw212. [CrossRef] 
147. Richardson, A.E.; Hadobas, P.A. Soil isolates of Pseudomonas spp. that utilize inositol phosphates. Can. J. Microbiol. 1997, 43, 509-516. [CrossRef]

148. Rodríguez, H.; Fraga, R.; Gonzalez, T.; Bashan, Y. Genetics of Phosphate Solubilization and Its Potential Applications for Improving Plant Growth-Promoting Bacteria-First International Meeting on Microbial Phosphate Solubilization; Velázquez, E., Rodríguez-Barrueco, C., Eds.; Springer: Dordrecht, The Netherlands, 2007; pp. 15-21.

149. Wei, K.; Sun, T.; Tian, J.; Chen, Z.; Chen, L. Soil microbial biomass, phosphatase and their relationships with phosphorus turnover under mixed inorganic and organic nitrogen addition in a Larix gmelinii plantation. For. Ecol. Manag. 2018, 422, 313-322. [CrossRef]

150. Anderson, O.R.; Juhl, A.R.; Bock, N. Effects of organic carbon enrichment on respiration rates, phosphatase activities, and abundance of heterotrophic bacteria and protists in organic-rich Arctic and mineral-rich temperate soil samples. Polar Biol. 2018, 41, 11-24. [CrossRef]

151. Spohn, M.; Treichel, N.S.; Cormann, M.; Schloter, M.; Fischer, D. Distribution of phosphatase activity and various bacterial phyla in the rhizosphere of Hordeum vulgare L. depending on P availability. Soil Biol. Biochem. 2015, 89, 44-51. [CrossRef]

152. Shen, L.; Wu, X.-Q.; Zeng, Q.-W.; Liu, H.-B. Regulation of soluble phosphate on the ability of phytate mineralization and $\beta$-propeller phytase gene expression of Pseudomonas fluorescens JZ-DZ1, a phytate-mineralizing Rhizobacterium. Curr. Microbiol. 2016, 73, 915-923. [CrossRef]

153. Zhao, K.; Penttinen, P.; Zhang, X.; Ao, X.; Liu, M.; Yu, X.; Chen, Q. Maize rhizosphere in Sichuan, China, hosts plant growth promoting Burkholderia cepacia with phosphate solubilizing and antifungal abilities. Microbiol. Res. 2014, 169, 76-82. [CrossRef] [PubMed]

154. Ku, Y.; Xu, G.; Tian, X.; Xie, H.; Yang, X.; Cao, C. Root colonization and growth promotion of soybean, wheat and Chinese cabbage by Bacillus cereus YL6. PLoS ONE 2018, 13, e0200181.

155. Kumar, S.; Bauddh, K.; Barman, S.C.; Singh, R.P. Amendments of microbial biofertilizers and organic substances reduces requirement of urea and DAP with enhanced nutrient availability and productivity of wheat (Triticum aestivum L.). Ecol. Eng. 2014, 71, 432-437. [CrossRef]

156. Valetti, L.; Iriarte, L.; Fabra, A. Growth promotion of rapeseed (Brassica napus) associated with the inoculation of phosphate solubilizing bacteria. Appl. Soil Ecol. 2018, 132, 1-10. [CrossRef]

157. Biswas, J.K.; Banerjee, A.; Rai, M.; Naidu, R.; Biswas, B.; Vithanage, M.; Dash, M.C.; Sarkar, S.K.; Meers, E. Potential application of selected metal resistant phosphate solubilizing bacteria isolated from the gut of earthworm (Metaphire posthuma) in plant growth promotion. Geoderma 2018, 330, 117-124. [CrossRef]

158. Nassal, D.; Spohn, M.; Eltlbany, N.; Jacquiod, S.; Smalla, K.; Marhan, S.; Kandeler, E. Effects of phosphorus-mobilizing bacteria on tomato growth and soil microbial activity. Plant Soil 2018, 427, 17-37. [CrossRef]

159. Samaddar, S.; Chatterjee, P.; Truu, J.; Anandham, R.; Kim, S.; Sa, T. Long-term phosphorus limitation changes the bacterial community structure and functioning in paddy soils. Appl. Soil Ecol. 2019, 134, 111-115. [CrossRef]

160. Research, G.V. Biofertilizers Market Size, Share and Trends Analysis Report by Product (Nitrogen Fixing, Phophate Solubilizing), by Application (Seed Treatment, Soil Treatment), and Segment Forecasts, 2012-2022; Grand View Research: San Francisco, CA, USA, February 2018; Report ID: 978-1-68038-038-5.

161. Kafle, A.; Garcia, K.; Peta, V.; Yakha, J.; Soupir, A.; Bücking, H. Beneficial plant microbe interactions and their effect on nutrient uptake, yield and stress resistance of soybeans. In Soybean-The Basis of Yield, Biomass and Productivity; Kasai, M., Ed.; IntechOpen: London, UK, 2018. [CrossRef]

162. Gibert, A.; Tozer, W.; Westoby, M. Plant performance response to eight different types of symbiosis. New Phytol. 2019. [CrossRef] [PubMed]

(C) 2019 by the authors. Licensee MDPI, Basel, Switzerland. This article is an open access article distributed under the terms and conditions of the Creative Commons Attribution (CC BY) license (http://creativecommons.org/licenses/by/4.0/). 